\title{
Plant Climbing in the Northern Two-lined Salamander, Eurycea bislineata, in Algonquin Provincial Park, Ontario
}

\author{
DAVID L. LEGROS \\ 935 Ramsey Lake Road, Laurentian University, Sudbury, Ontario P3E 2C6 Canada
}

LeGros, David, L. 2013. Plant climbing in the Northern Two-lined Salamander, Eurycea bislineata, in Algonquin Provincial Park, Ontario. Canadian Field-Naturalist 127(1): 67-69.

Lungless salamanders (Plethodontidae) are often active on the surface on rainy evenings, and some species may even climb vegetation in search of prey. Here I report the first investigation of plant climbing in the Northern Two-lined Salamander (Eurycea bislineata). Surveys were carried out along Bat Lake Creek in Algonquin Provincial Park over four rainy nights in summer 2007 for Northern Two-lined Salamanders. I compared the numbers of Northern Two-lined Salamanders foraging on the ground with those climbing on plants, and over half of the Northern Two-lined Salamanders were climbing plants. This behaviour may provide the Northern Two-lined Salamander with access to an underutilized food source, and plants may represent an additional foraging habitat for this species.

Key Words: Northern Two-lined Salamander (Eurycea bislineata), plant climbing, foraging, Algonquin Provincial Park, Ontario.

Lungless salamanders (Plethodontidae) are important components of forest floor and stream ecosystems in eastern North America, providing the majority of small vertebrate biomass in some forests (Burton and Likens 1975a, 1975b). Most studies of the prey items of these salamanders have sampled stomach contents from Eastern Red-backed Salamanders (Plethodon cinereus) collected in the leaf litter (Jaeger 1978, 1980), reinforcing the assumption that lungless salamanders restrict their foraging to the immediate substrate. However, lungless salamanders may forage in other habitats, exploiting invertebrates, such as phytophagous insects, not normally associated with forest leaf litter.

Lungless salamanders are extremely sensitive to environmental conditions, such as ambient air temperature and soil moisture (Spotila 1972). When exposed to dry conditions, lungless salamanders rapidly lose water and have a restricted foraging time (Feder and Londos 1984). Similarly, during dry periods, prey may also be limited, further reducing foraging opportunities (Jaeger 1980). To avoid dry conditions, lungless salamanders seek refuge under cover, where humidity remains consistently high. Typically, lungless salamanders emerge to forage at night or under wet conditions (Spotila 1972).

On rainy nights, Eastern Red-backed Salamanders have been observed climbing plants, presumably to exploit underutilized food sources (Jaeger 1978). Although Eastern Red-backed Salamanders and Northern Two-lined Salamanders (Eurycea bislineata) have similar diets and body sizes (Petranka 1998), plant-climbing behaviour has not been documented in the Northern Two-lined Salamander. After a thorough review of the literature, I believe this is the first report of plant climbing in the Northern Two-lined Salamander. I report the results of a survey to determine the frequency of plantclimbing behaviour of the Northern Two-lined Salamander in central Ontario, near the northern limit of the species' range (Petranka 1998).

\section{Methods and Materials}

Surveys of Northern Two-lined Salamanders were conducted on four nights between 23 June and 29 August 2007 along Bat Lake Creek, a small stream in Algonquin Provincial Park, Nipissing District, Ontario $\left(45^{\circ} 35^{\prime} \mathrm{N}, 78^{\circ} 32^{\prime} \mathrm{W}\right)$. After dark on rainy evenings, or following an afternoon rain (2000 to 2330), 1-7 people surveyed Bat Lake Creek by walking the banks and visually searching for salamanders active on the surface. We watched for salamanders on rocks and debris or climbing on vegetation in the stream or on the stream bank within $1 \mathrm{~m}$ of the water's edge. When one was located, its location (on the ground or elevated on a plant or log) was noted. Salamanders were considered to be "on the ground" when observed in the open on leaf litter overlying the soil substrate, and were considered to be "climbing a plant" when found above the soil-litter substrate on live or dead vegetation.

All Northern Two-lined Salamanders observed were captured, after which they were sexed (based on presence or absence of the mental gland) (Petranka 1998), and snout-vent (SVL) and total length (TL) were measured with Vernier callipers. Northern Two-lined Salamanders were then released at site of capture.

Area surveyed was measured with a vinyl tape and calculated as stream length $\times$ stream width, the latter incorporating $1 \mathrm{~m}$ of stream bank on each side of the watercourse. Nightly sampling effort is here defined as the number of total person-hours of sampling per night. A $\chi^{2}$ test of independence was conducted to determine whether there was a significant difference between the number of Northern Two-lined Salamanders on the ground and climbing on plants.

\section{Results}

During four night-time sampling events between 23 June and 29 August 2007, 19 adult Northern Twolined Salamanders were captured. The average snoutvent length of these individuals was $31.8 \mathrm{~mm}$ (SD 1.3). 
TABle 1. Locations of Northern Two-lined Salamanders (Eurycea bislineata) (on the ground or climbing plants) captured along Bat Lake Creek, Algonquin Park, Ontario, in summer 2007. Effort is defined as the number of hours spent searching the creek and bank $\left(1 \mathrm{~m}\right.$ on each side of the stream bank) $\times$ the number of persons searching; the area $\left(\mathrm{m}^{2}\right)$ was defined as the length of stream $\times$ the width of the stream and $1 \mathrm{~m}$ on each stream bank.

\begin{tabular}{lcccccccc}
\hline \hline $\begin{array}{l}\text { Date } \\
(2007)\end{array}$ & $\begin{array}{c}\text { \# Salamanders } \\
\text { on Ground }\end{array}$ & $\begin{array}{c}\text { \# Salamanders } \\
\text { Plant Climbing }\end{array}$ & Total & Persons & $\begin{array}{c}\text { Effort } \\
\text { (hours) }\end{array}$ & $\begin{array}{c}\text { Area } \\
\left(\mathrm{m}^{2}\right)\end{array}$ & $\begin{array}{c}\text { Salamanders } \\
\text { per hour }\end{array}$ & $\begin{array}{c}\text { Salamanders } \\
\text { per } \mathrm{m}^{2}\end{array}$ \\
\hline 23 June & 0 & 1 & 1 & 1 & 1 & 90 & 1 & 0.01 \\
8 July & 3 & 7 & 10 & 3 & 4.5 & 222 & 2.22 & 0.04 \\
14 July & 4 & 0 & 4 & 2 & 1.33 & 105 & 3.00 & 0.03 \\
29 August & 1 & 3 & 4 & 7 & 7.58 & 150 & 0.52 & 0.02 \\
Total & 8 & 11 & 19 & 13 & 14.41 & 567 & 1.31 & 0.03 \\
\hline \hline
\end{tabular}

Eight of the Northern Two-lined Salamanders were on the ground in the open and around rocks, and 11 were on vegetation and fallen logs, ranging from 10 to $45 \mathrm{~cm}$ above the ground (Table 1). The $\chi^{2}$ test revealed no difference between Northern Two-lined Salamanders on the ground and climbing plants $\left(\chi^{2}=7.30, \mathrm{df}=3\right.$, $P=0.06)$.

\section{Discussion}

Nocturnal surface activity of stream-dwelling salamanders commences at dusk and peaks approximately 1 hour after dark (Holomuzki 1980). In the study reported here, just over half of the 19 Northern Two-lined Salamanders observed on wet nights were climbing vegetation. Although there was no significant difference between the number of Northern Two-lined Salamanders on the ground and climbing plants, it does suggest that plant-climbing behaviour is common at this location.

Jaeger (1978) reported that Eastern Red-backed Salamanders climb plants to gain access to an underutilized food source - plant-dwelling insects. Jaeger (1978) also suggested that climbing single stems and foraging for insects on the foliage provided a two-dimensional habitat that was less complex than the three-dimensional habitat in the leaf litter, thus facilitating the capture of insects. The value of plant-climbing behaviour as an important foraging technique for these salamanders is further supported by Jaeger's (1978) work, which revealed that Eastern Red-backed Salamanders that climbed plants had significantly greater volumes of arthropod prey in their stomachs than individuals found in the leaf litter. Jaeger (1978) also found that these plant-climbing Eastern Red-backed Salamanders had larger prey items in their stomachs, mainly plantdwelling insects (Hemipterans and Homopterans), than those foraging in the leaf litter.

Although I did not collect Northern Two-lined Salamanders to analyze the stomach contents, it seems likely that Northern Two-lined Salamanders engaging in plant climbing were consuming arthropod prey captured on vegetation. It is also noteworthy that the timing of plant-climbing behaviour (the hours after sunset) coincides with peak activity of plant-dwelling insects (Holomuzki 1980).
Northern Two-lined Salamanders typically inhabit streams and seeps (Petranka 1998), but they are known to venture considerable distances into the adjacent forest (MacCulloch and Bider 1975). The surveys presented here were limited to the stream bank (within $1 \mathrm{~m}$ of the stream edge); therefore, any individuals further away from the stream, whether in the leaf litter or climbing on vegetation, were not captured. Because Northern Two-lined Salamanders were not looked for under rocks, many individuals were likely not counted.

This is the first report of plant climbing in the Northern Two-lined Salamander. However, this behaviour is not unexpected. In addition to the Eastern Red-backed Salamander, other Plethodon ssp. and juvenile Ambystoma ssp. have been observed climbing plants (Burton and Likens 1975a; Jaeger 1978; Smith et al. 2011; Osbourn et al. 2012). Generally, salamanders within the genera Plethodon, Aneides, and Eurycea are competent climbers, and some salamander species live in vertical habitats, such as trees, rock crevices, cliffs, and caves (Noble and Marshall 1929; Stebbins 1951; Peck and Richardson 1976).

Lastly, due to the secretive and nocturnal nature of Northern Two-lined salamanders, plant climbing in this species may have been noted previously but not published. One such opportunistic observation was made of a single Northern Two-lined Salamander (Canadian Museum of Nature 2834, $2 \mathrm{~km}$ south of Bishopton, Quebec, 4 June 1954, collected by J. S. Bleakney and F. R. Cook) climbing on a stem projecting above the water among tufts of grass among a Pseudacris crucifer (Spring Peeper) chorus in a flooded field with a stream flowing through it (F. R. Cook, Canadian Museum of Nature, personal communication, 2013).

New techniques to study the movements of salamanders, such as using fluorescent powders (Smith et al. 2011), may yield new observations of plant climbing in other species in the future. If stream salamanders regularly make forays into stream-side habitats and climb plants in search of prey, conservation of both streams and their adjacent riparian habitat may be required to maintain populations.

\section{Acknowledgements}

The author wishes to thank Algonquin Provincial Park for allowing the surveys to be made and provid- 
ing a vehicle to carry out the research. Many thanks to those Algonquin Park Visitor Centre staff who assisted in collecting data on rainy nights. I must also thank the two anonymous reviewers for their comments.

\section{Literature Cited}

Burton, T. M., and G. E. Likens. 1975a. Salamander populations and biomass in the Hubbard Brook Experimental Forest, New Hampshire. Copeia 1975: 541-546.

Burton, T. M., and G. E. Likens. 1975b. Energy flow and nutrient cycling in salamander populations in the Hubbard Brook Experimental Forest, New Hampshire. Ecology 56: 1068-1080.

Feder, M. E., and P. L. Londos. 1984. Hydric constraints upon foraging in a terrestrial salamander, Desmognathus ochrophaeus (Amphibia: Plethodontidae). Oecologia 64: 413-418.

Holomuzki, J. R. 1980. Synchronous foraging and dietary overlap of three species of Plethodontid salamanders. Herpetologica 36: 109-115.

Jaeger, R. G. 1978. Plant climbing by salamanders: periodic availability of plant-dwelling prey. Copeia 1978: 686-691.

Jaeger, R. G. 1980. Fluctuations in prey availability and food limitations for a terrestrial salamander. Oecologica 44: 335-341.

MacCulloch, R. D., and J. R. Bider. 1975. Phenology, migrations, circadian rhythm and the effect of precipitation on the activity of Eurycea b. bislineata in Quebec. Herpetologica 31: 433-439.

Noble, G. K., and B. C. Marshall. 1929. The breeding habits of two salamanders. American Museum Novitates 347: $1-12$.

Osbourn, M. S., S. E. Pittman, D. L. Drake, and R. D. Semlitsch. 2012. Ambystoma annulatum (Ringed Salamander) and Ambystoma maculatum (Spotted Salamander): climbing behaviour. Herpetological Review 43: 458-459.

Peck, S. B., and L. Richardson. 1976. Feeding ecology of the salamander Eurycea lucifuga in the entrances, twilight zone, and dark zone of caves. Annales de Spéléologie 31: $175-182$.

Petranka, J. W. 1998. Salamanders of the United States and Canada. Smithsonian Institution Press, Washington, D.C. 585 pages.

Smith, W. H., H. Cunningham, and A. Hall. 2011. Plethodon glutinosus (Northern Slimy Salamander): arboreal habitat use. Herpetological Review 42: 582-582.

Spotila, J. R. 1972. Role of temperature and water in the ecology of lungless salamanders. Ecological Monographs 49: 95-125.

Stebbins, R. C. 1951. Amphibians of Western North America. University of California Press, Berkeley, California. 539 pages.

Received 18 January 2013

Accepted 5 February 2013 